\title{
İran Siyasetinde Dini Lider ve Cumhurbaşkanı İlişkileri: Hasan Ruhani'nin Birinci Dönemi Örneği ${ }^{1}$
}

\author{
Alaeddin Yalçınkaya ${ }^{2}$ \\ Yasemin Konukcu ${ }^{3}$
}

\begin{abstract}
Öz
İran'da 1990'lı yıllardan itibaren, Humeyni döneminde baskı altına alınan siyasetin rekabetçi özellikleri yeniden ortaya çıkmıştır. SSCB'nin dağılması, ABD'nin siyasi ve ekonomik yapısının talep edilebilir tek sistem algısını güçlendirirken, bu durum íran siyasetinde özellikle ekonomik konularda görüş ayrılıklarının ortaya çıkmasına zemin hazırlamıştır. Aynı tarihlerde kurumsallaşma sürecini büyük ölçüde tamamlayan Rejim, kendi içinde çatışma alanları yaratarak dönüşümünü sürdürmüştür. Böyle bir ortamda, İran siyasetinin öne çıkan iki aktörü, dini lider ve cumhurbaşkanı siyasi rekabet sahalarında dinamik bir ilişki biçimi oluşturmuşlardır. Bu ilişkide, güç mücadelesi ve işbirliği çeşitli derecelerde gözlemlenmekle birlikte, Reformcular ve Muhafazakârlar arasındaki rekabetin temel karakteri de ortaya çıkmıştır.
\end{abstract}

Anahtar Kelimeler: İran, siyasal rekabet, nükleer anlaşma, ABD-i̇ran ilişkileri.

\section{Religious Leader And President Relations In Iran Politics: Hasan Ruhani's First Period Example}

\begin{abstract}
Since the 1990 in Iran, the competitive features of politics, which were under pressure during the Khomeini period, have re-emerged. While the collapse of the USSR, strengthens the perception that the political and economic structure of the United States is the only demandable system, this has led to disagreements in Iranian politics, especially in economic matters. The Regime, which completed the institutionalization process to a large extent on the same dates, has continued to transform itself by creating conflict zones. In such a condition, the two prominent actors of Iranian politics, the religious leader and the president, have formed a dynamic relationship in the fields of political competition. In this relationship, power struggle and cooperation have been observed at various levels, while the main character of competition between Reformers and Conservatives has emerged
\end{abstract}

Keywords: Iran, political competition, nuclear agreement, US-Iran relations.

\footnotetext{
${ }^{1}$ Bu makale, “Küresel Hegemonya ve Güç Dengeleri Bağlamında ABD-iran ilişkileri” isimli doktora tez çalışmasından üretilmiş ve geliştirilmiştir.

2 Prof. Dr., Marmara Üniversitesi Siyasal Bilgiler Fakültesi, Uluslararası İlişkiler Bölüm Başkanı, alaeddin.valcinkaya@marmara.edu.tr

3 Marmara Üniversitesi Ortadoğu ve İslam Ülkeleri Araștırmaları Enstitüsü Doktora Öğrencisi, ykonukcu2003@yahoo.com
}

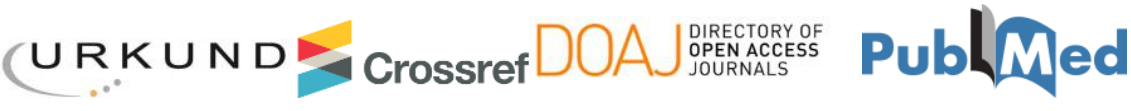




\section{Giriș}

Kuruluş nitelikleri itibariyle, dünya siyasetinde benzersiz özellikler taşıyan İran devlet sisteminin iki önemli aktörü, Uzmanlar Meclisi (Meclis-i Hubregan-i Rehberi) tarafından belirlenen dini lider ve halkoyuyla seçilen cumhurbaşkanıdır. Bu çalışmada devrim sonrası liderler ve cumhurbaşkanları arasında yaşanan siyasal çatışmalar analiz edilmektedir. $\mathrm{Bu}$ çatışmaların niteliği üzerinden İran siyasal sisteminin tartışmaya açık konuları ve bu konuların sınırları anlaşılmaya çalışılmaktadır. Dönem olarak Ruhani'nin Cumhurbaşkanı seçildiği 2013 seçimleri sonrası yakın plana alınmıştır.

Devrim sonrası İran siyasetinin kuruluş felsefesini belirleyen en önemli aktör, kuşkusuz Ayetullah Humeyni'dir. Humeyni, siyasal rakiplerine, devrimin ateşi ve Irak'la yaşanan savaş nedeniyle, açıktan ve meșru muhalefet hakkını ve imkânını tanımamıştır. Humeyni'nin ölümünden sonra İran'da çeşitli siyasal görüş ayrılıkları ve mücadelelerde açıktan verilmeye başlanmıştır. Bu mücadelelerin en belirgin şekilde yaşandığı merkezlerin başında da dini lider ve cumhurbaşkanlığı makamları gelmektedir.

İran siyaseti hiyerarşik bir yapı içermekle birlikte, ülkede siyasi eksenlerin gelişmesiyle canlı bir rekabetin önü de açılmış bulunmaktadır. Bu rekabet, zaman zaman rejimin temel yapısını sorgulamaya kadar gidebilmektedir. Dini liderin sahip olduğu siyasi gücün, $A B D$ ve $A B$ ile ilişkilerin, kültür, eğitim ve ekonomi alanında farklılaşmaların tartışılması, cumhurbaşkanı ve lider'in çeşitli zeminlerde çatışmasına neden olmaktadır. Ruhani'nin birinci döneminde, cumhurbaşkanı ve dinî liderin ilişkilerinin ana hatlarının değerlendirilmesi, İran siyasetinin güncel dinamizmine dair önemli ayrıntılar içermektedir.
Ali Hamaney, 1989 Haziran ayında Uzmanlar Meclisi tarafından ülkenin dini lideri olarak seçilmiştir. 28 Temmuz 1989'da Anayasa'da' yapılan değişikliklere göre, dış politikanın belirlenmesi, dinî vakıflar, askerî ve adlî kurumlarda atamaların yapılmasının yanında İran Anayasa Muhafızları Konseyi'nin 6 üyesini seçme haklarını elinde bulunduran lider, ülke siyasetine büyük ölçüde yön vermektedir ancak yine de riskten kaçınma ve statükoyu koruma eğilimi nedeniyle her şeye gücü yeten bir otokrat değildir. (Green, vd. 2008)

İran siyasetinde cumhurbaşkanları doğrudan "Rejimin Rehberine" bağlı olmayan konularda yürütme yetkisine sahiptir. Bu yetkiler uluslararası anlaşmaların imzalanması, bütçenin hazırlanması, büyükelçilerin atanması, İran'da görev yapan elçilerin güven mektubunun kabulü ve bakanların belirlenerek onay için Meclise sunulmasıdır. (Kılınç:2008, 927-928).

Ahmedinejad'ın arkasından 2013 yılında seçilen Hasan Ruhani, siyasete Humeyni sempatizanı olarak başlamıştır. Devlet bürokrasisine ve Rafsancani'ye yakınlığıyla tanınan Ruhani, Irak Savaşı sırasında, 'Yüksek Savunma ve Savașı Destekleme Üst Konseylerinde' görev yapmıştır. 1988'de ise, Ordu komutanı olmuştur. 1992-2013 yılları arasında Stratejik Araştırmalar Merkezi başkanlığı görevine yürüten Ruhani (Çitlioğlu:2005, 55) sözü edilen kişisel geçmişi sayesinde bir "denge" unsuru olarak öne çıkmıştır.

2013 yılında Cumhurbaşkanı seçilen, pragmatik ve merkeziyetçi (Secor:2017) olarak tanımlanan Ruhani, sınırlı yetkilerine ve etkisine rağmen, geçen zaman içinde küresel ve bölgesel gelişmelerin katkısıyla İran siyasetinde reformcu arayıșları özellikle dış politikada belli ölçüde hayata

\footnotetext{
1 İran Anayasası için bkz. "Iran (Islamic Republic of)'s Constitution of 1979 with Amendments through 1989", https://www.constituteproject.org/constitution/Iran_1989. pdf?lang=en, 19.07.2017. Anayasa'nın 57, ve 110 . maddelerinde dini liderin görev ve yetkileri belirlenmiştir. Ayrıca Anayasa'nın 15, 111, 113, 126, 128 ve 129 maddelerde de cumhurbaşkanının yetkileri tanımlanmıştır.
} 
geçirebilmiștir. Ancak bu durum Cumhurbaşkanı açısından, siyasal çatışmaların, darbe söylentilerinin, yargılanma tehditlerinin ve nükleer anlaşmanın sekteye uğraması ihtimalinin gölgesinde ve ağır aksak bir şekilde gerçekleşebilmiştir.

\section{Dıș Politika}

İdeolojik ve pragmatik olarak İran dış politikasının genel çerçevesini, Rıza Şah döneminin mirası, yaşanan siyasi çatışmalar, uluslararası tecrit ortamının zorunlulukları ve içeriğini Ayetullah Humeyni'nin oluşturduğu Velayet-i Fakih (Taflıoğlu: 2013, 95-112) doktrini belirlemiştir. Humeyni'nin ölümünden sonra, iç politikada yaşanan ayrışmalar doğal olarak dış politika anlayışları farklı siyasal temsillerin ortaya çıkmasına neden olmuştur. Genel hatlarıla Muhafazakârlar, Humeyni'nin Batı ve Amerikan karşıtı ideolojik söylemlerini, "direniş ekonomisi" iddiasını ve kültürel içe kapanma eğilimini devam ettirirken, (Mansfield:2011, 465) Reformcular özellikle ekonomik işbirliği konusunda Batı ile yakınlaşma siyasetini benimsemektedirler. Reformcuların önemli aktörlerinden sayılan Haşimi Rafsancani, ekonomik liberalizmi, Muhammed Hatemi, siyasal liberalizmi ve son olarak Ruhani, dengeli bir ekonomik ve siyasal liberalizmi savunmaktadır.

Ekonomide liberalleşme adımlarını destekleyen Ruhani, dış politikada ve Batı ile ilişkilerde itidal ve uzlaşı arayışını benimseyen bir çizgide durmaktadır. Aynı zamanda dış politika konusunda Ruhani, Hamaney tarafından belirlenen bölgesel güvenlik politikalarını benimserken, Batılı ülkelerle ilgili söylem ve hareket tarzı ile Dini liderden farklı bir bakış açısına sahip olduğunu da göstermiştir.

Ancak, sözü edilen farklılığın Hamaney'in ve Devrim Muhafızlarının (DM) bölgesel politikalarını sorgulamak anlamına gelmediğini de belirtmek gerekir. İran'ın bölgesel politikası bir hükümetin siyasal eğilimin yansıması değil daha ziyade bir devlet politikasıdır. Irak ile yaşanan savaştan sonra İran, rejim ve ülke güvenliğini sınırları dışında, Aden, Basra ve Akdeniz'de oluşturulan savunma hattına dayalı olarak stratejik bir düşünce ile şekillendirmiştir. (Alaca: 2017) Hamaney tarafından belirlenen ve DM tarafından uygulanan bölgesel politikalarla uyumlu davranan Ruhani İran'ın, Irak ve Suriye'de yaşanan çatışmalarda lojistik ve fiili varlığını savunmaktadır. Hatta Ruhani, “DM bugün yalnızca ülkenin güvenlik yükünü omuzlarında taşımıyor, İslami İran'dan yardım isteyen ülkelerin güvenliğini de sağlıyor ve bütün gücüyle o meydanlarda bulunuyor" (Sinkaya:2016) şeklinde desteğini açıç̧a ifade etmiştir. Ruhani hükümetinin DM'nın bölgesel politikalarına söylem düzeyindeki desteği, askeri harcamalara genel bütçeden ayrılan oranın sürekli arttırılmak suretiyle filli olarak da hayata geçirilmiştir. (bkz. NTV:2016).

Ruhani'nin söylemleri ile Hamaney'in yaklaşımları farklılaşmakla birlikte, dış politika konularında belirleyici konumda yer alan aktörler lider Hamaney ve kendisine bağlı olan askeri bürokrasidir. Ruhani dönemimde bu durum önemli bir değişim göstermemiştir. Ancak, 2015 yllından P5+1 ülkeleri ve İran arasında yapılan nükleer anlaşma sonrasında, Ruhani ve Hamaney arasında siyasi gerilimlerin gözle görünür şekilde arttığı söylenebilir.

\section{Nükleer Anlașma ve Değișen Dengeler}

İran'ın nükleer programı, ülkenin uluslararası toplumla yaşadığı gerilimlerin başlıca nedenleri arasındadır. Hamaney ve Ruhani'nin, nükleer çalışmalar ve nükleer anlaşmaya yaklaşımları birbirinden farklılık göstermektedir. Nükleer anlaşma Ruhani yönetimi tarafından bir iftihar meselesi olarak görülürken, Hamaney ve özellikle Devrim Muhafızları nükleer bir güç olmayı ve bu amaç doğrultusunda yürütülen çalışmaları "ulusal onur" ve bir ideal meselesi olarak değerlendirmektedirler. Aynı zamanda ülkedeki nükleer çalışmaların arkasındaki itici güç de Devrim Muhafızlardır. 
2015 yılında imzalanan Nükleer anlaşma belli bir zaman dâhilinde, İran'ın zenginleştirilmiş uranyum stokunun azaltılması, nükleer tesislerin denetlenmesi ve sayılarının azaltılması ve nükleer kapasite geliştirmeye dönük çalışmaların nükleer silah elde edecek düzeyin altında tutulmasının garanti altına alınması karşılı̆̆ında, (Kissinger, Shultz:2015) kademeli olarak İran'a uygulanan BM yaptırımlarının kaldırımasını hedeflemektedir.

Nükleer anlaşma, İran siyaseti açısından yalnızca çok taraflı bir mutabakat değil, aynı zamanda, ülkenin siyasi, ekonomik ve kültürel yapısında dönüştürücü bir potansiyel ifade etmektedir. Obama yönetimi, nükleer anlaşma ile İran'ı küresel sistemle uyumlu bir ülke haline getirmeyi hedeflemiştir. Kısacası nükleer anlaşmanın İran siyasetindeki reformcu eğilime katkı vermesi ve $A B D$ ve İsrail karşıtlığı üzerine kurulu muhafazakâr söylemin elini zayıflatması beklenmiştir. (Çagaptay, vd. 2015).

$\mathrm{Bu}$ durumun farkında olan ülkedeki Muhafazakâr bileşenler, anlaşma öncesinde Reformcuları kaygilandırmaktaydılar. 2014 yılının Kasım ayında, Sahamnews isimli bir internet sitesinde, DM İstihbarat teşkilatı, kendisi de eski bir devrim muhafızı olan Ahmedinejad'a yakın bazı isimler ve Cemiyet-i İsargaran mensuplarının gizli olarak darbe planladığına dair bir makale yayınlanmıştır. (Sinkaya:2016) Ancak darbe söylentisi Reformcular arasında psikolojik bir baskı unsuru olmanın ötesine geçmemiştir.

Ruhani ve Hamaney arasındaki nükleer anlaşma konusundaki mücadele düşük yoğunluklu bir şekilde devam ederken, DM ile Cumhurbaşkanı arasındaki söz düellosu açıkça gözlemlenmektedir. Ruhani, nükleer anlaşmanın onaylanmasından sonra DM tarafından yapılan füze denemelerini uzlaşmaya yönelik bir sabotaj olarak değerlendirmiş ve bu iddiasını 19 Mayıs Cumhurbaşkanlığı seçim süreci sırasında da dile getirmiştir.
Diğer taraftan Hamaney anlaşma üzerinden $A B D$ yönetimine karşı eleştirilerini sürdürmüş, İran'a uygulanan ekonomik ambargoların kaldırılmadığını ve ABD'nin kendilerini “kandırdığını" belirtmiştir. Aynı şekilde Ruhani'nin uzlaşma arayışına karşın Hamaney, "Iran rejimine karşı düşmanın emellerinden vazgeçmediğini" ifade etmiş ve nükleer anlaşmadan sonra $A B D$ ile ilişkilerde ihtiyatlı olma konusunda ısrarcı davranmıştır. (Cladstone::2017)

$\mathrm{Bu}$ bağlamda Ruhani, yalnızca nükleer anlaşmayı çok taraflı olarak imzalamamış, İran'da tabu haline getirilmiş bir konu olan Amerikan karşıtlığının da tartışıması için güçlü bir zemin yaratmıştır. Çünkü nükleer anlaşma, Ruhani ve Dışişleri Bakanı Zarif tarafından, İran'ın rejim güvenliğinin silahlanma yoluyla değil küresel aktörlerle uzlaşma zemininde çözme iradesinin de bir yansıması olarak sunulmuştur. Bu durum, hem Hamaney hem de Devrim Muhafızlarının tepkisine neden olmuştur. Nitekim Lider, düşmanın (ABD) kültürel ve ekonomik araçlarla ülkeye "sızma" çabasına devam ettiğini vurgulamıştır.

Nükleer anlaşma uluslararası toplumla İran arasında bir sorun olduğu kadar ülkede etkili güç unsurları arasında da bir mücadele konusudur. Anlaşma üzerinden yürütülen mücadelelerin arakasında ekonomik ve siyasal motivasyonlar bulunmaktadır.

\section{Devrim Muhafızları ve Ekonomi}

Devrim Muhafızları ideolojik olarak içerde ve dışarıda örgütlenmiş bir güvenlik ağıdır. Ancak yalnızca bu değildir. Devrimin ihyası, toplumun "ıslahı", ülkenin imarı ve rejimin güvenlik ihtiyacına dair örgütlenmeler bu kurumun çatısı altında toplanmıştır. Böylelikle DM gönüllülerin eğitilmesi, ticarî ve mali kurumlar, medya ve siyaset alanlarını da kapsayan geniş bir ağa sahip olmuştur. Kuruluş amacı, devrimi korumak ve devrimin ideolojik yapısı teminat altına almak olarak belirlenen DM, bu yaklaşım gereği Hamaney ve muhafazakâr siyasal eğilimlere yakın görünmekte, reformcu siyasilere açıktan muhalefet etmektedir. 
Muhammed Hatemi döneminde, 24 DM komutanının "uyarı" niteliğinde kaleme aldıkları mektuptan sonra, komutanların cumhurbaşkanı düzeyinde siyasal müdahaleleri açıç̧a gözlemlenmeye başlanmıştır. Gizli gönderilen ve daha sonra muhafazakâr gazetelerde yayınlanan mektupta, komutanlar Hatemi yönetimine "sabırlarının taştığını" açıkça ifade etmişlerdir. 2004 yılında ise, Uluslararası İmam Humeyni Havaalanı, hükümetin iradesi dışında DM tarafından işgal edilerek sözlü müdahaleler fiiliyata geçirilmiştir. (Sinkaya,:2010, 115-142).

Özellikle 2009 yılında yaşanan protestolarda, DM'na bağlı olarak kurulmuş ve gönüllü birliklerden oluşan Besic ${ }^{2}$ güçlerinin Yeşil Hareket'in (ayrıntılı bilgi için Dabashi:2011) bastırılmasındaki rolü nedeniyle, Ahmedinejad döneminde askerin siyasetteki belirleyiciliği artmıştır. 2009 yılındaki protestolardan sonra, düşük gelirli toplumsal kesimlere yönelik teşvikler ve devlet yardımları ile birlikte (Çağlayan:2012, 246) İran'ın ekonomik kaynaklarının önemli bir bölümü orduya aktarılmıştır.

Ekonomik açıdan ise, DM'nın siyasiler ve Hamaney'le ilişkileri tek boyutluluk arz etmemektedir. DM'nin ekonomik bir aktöre dönüşmesinde İran-Irak Savaşı kadar, Hamaney'in özellikle de 199o'da kurduğu Hatemü-I Enbiya Karargahı'nın ${ }^{3}$ çok önemli etkisi bulunmaktadır. Başlangıçta savaşta harap olan alt yapıyı yeniden inşa etmek için oluşturulan kurum DM bünyesinde bulunmakta ve önemli ihalelerde adından sıkça söz ettirmektedir. 2000'li yıllarda Basra Körfezindeki petrol sahaları da söz konusu şirketlere devredilmiştir. DM, bütçeden aldıkları oranın yanında, ek gelirler ve fonlarla da sık sık gündeme gelmektedir. DM, aynı zamanda çeşitli basın kuruluşları (örn Vatan-ı

\footnotetext{
${ }^{2}$ Gönüllü birliklerden oluşan Besic, devrimci kültürü yaşatma ve kültürel ve siyasi "saldırılara" veya muhalefete karşı gerekli görüldüğünde mücadele etmesi için örgütlenmiştir. Bkz. Abdullah Yeğin, “İran'ın Sert Gücü”, SETA, Şubat 2016, Say1 150, s. 14 ,

https://stratejisite.files.wordpress.com/2016/02/rann-sertgc.pdf, 12.06.2017.

${ }^{3}$ Bkz. İran'da Askerin Rolü, Anadolu Ajansl, http://aa.com.tr/tr/analiz-haber/iranda-askerinekonomide-rolu-tartismasi/560957, 05.06.2017.
}

İmruz ${ }^{4}$ ) aracıllğıyla İran kamuoyuna da yön vermektedir.

Devrim muhafızları siyasal açıdan Hamaney’le aynı çizgide görünmekle birlikte, bazı komutanların Rafsancani ve Ruhani'ye yakınlıkları da tartışma konusu yapılmaktadır. Özellikle İran-Irak Savaşı sırasında yeniden imar çalışmalarında Rafsancani'nin iktisadi politikalarının Muhafızların ekonomik bir güç haline gelmesinde önemli katkısı olduğu değerlendirilmektedir. Bunun yanında rejimin tehdit altında olduğu algısı, DM'nın ekonomik olarak büyümesinin zeminini de yaratmıştır.(Gregory:.2017)

$\mathrm{Bu}$ arka plana bağlı olarak iç politikada Ruhani ile DM komutanlarını karşı karşıya getiren temel konuların başında ekonomi gelmektedir. Bir taraftan, DM'nın ekonomik faaliyetlerini sınırlandırmaya çalışan Ruhani, diğer taraftan kapitalizmin sembolik ve fiili karar mekanizmalarından sayılan Davos Ekonomik Formu'na son on yılda katılan ilk cumhurbaşkanı olmuştur. Aynı zamanda Ruhani, ABD öncülüğünde Batının uygulamakta olduğu ambargo nedeniyle ekonomik çıkar sağlayan çevrelerin olduğunu sıklıkla dile getirmiştir. Ruhani ülke içindeki mali kurumların denetime açık olması gerektiğimi de ifade etmektedir. Bu durum doğal olarak ülkenin iki büyük ekonomik aktörü olan ve ekonomik varlıkların yaklaşık olarak\% 80'ni elinde tutan din adamlarının ve DM'nın denetlemesi anlamına gelmektedir.

Din adamları vakıflar yoluyla ve DM komutanları da büyük ihaleler alarak ülkenin en önemli ekonomik aktörleri haline gelmişlerdir. Örneğin, “íslam Cumhuriyeti'nin kurucusu Ayetullah Humeyni'nin ölümünden kısa süre önce kurduğu 'Setad' vakfı, 90 milyar dolar!” (Kohlmann,:2017) kontrol etmektedir. Bu bağlamda Ruhani'nin özel sektörün önündeki engellerin kaldırılması ve yabancı sermayenin İran'a yatırım için teşvik edilmesine yönelik politikaları, hem askerlerin hem de din adamlarının iktisadi çıkar ve vizyonlarıla çelişmektedir. (Hakimian:.2017) Reformcu Şark gazetesi, 22 Temmuz'da DM sözcüsü Ramazan Şerif'le bir

${ }^{4}$ Bkz.http://www.vatanemrooz.ir/ 
söyleşi yayımlamıştı. DM'nın ekonomik faaliyetleri ve güdülen mantığın sorgulandığı söyleşide, Şerif oldukça zorlanmış ve iktisadi faaliyetlerin nedeninin ekonomik çıkar amaçlı değil "ulusal menfaat" gözetilerek yapıldığını ifade etmiştir. (Avaei: 2017)

Ekonomik bir aktör olmanın yanından denetlenemeyen DM komutanlarının isimleri yolsuzlukla da anılmaktadır. Hamaney'in, DM'nın ekonomik faaliyetlerinden ve özellikle komutanlarının adlarının sınır kaçakçılığı ile anılmasından rahatsız olduğu bilinmektedir. Bu konuda Ruhani ve Hamaney aynı çizgide görünmekle birlikte farklı ihtimallerin varlığını da göz önünde bulundurmak gereklidir.

Esas mesele, DM'nın, kendi aralarında siyasal ayrılıkların da olduğu göz önünde bulundurulursa, Hamaney'in kendisine uzak gördüğü ve Ruhani'ye destek verdiği tahmin edilen komutanları yolsuzluk ithamları eșliğinde tasfiye etmeyi düşünebilmesiyle ilgili olabilir.

Ruhani döneminde DM komutanları, tarihsel olarak siyasi bir kurum olması nedeniyle, aktif bir muhalefet gibi davranmıştır. Kısacası, DM'nın muhafazakâr görünümü nedeniyle, Hamaney ve Ruhani arasındaki gerilimlerde, güç ibresi genellikle dinî liderden yana olmuştur. DM'nin siyasal alanda etkinliği, iç ve dış tehdit bağlamında şekillendirildiği için, Ruhani'nin "denge" siyaseti konjonktüre bağlı bir başarı olarak değerlendirilebilir.

\section{Batı Kültürü, Etnik ve Dini Meseleler}

İran toplumu etnik ve dini olarak çeşitlilik arz etmektedir. Farslar, Azeriler, Kürtler, Araplar, Beluçlar, Türkmenler, Ermeniler ve Yahudiler ülkedeki etnik ve dini unsurları oluşturmaktadır. Bunun yanında İran devletinin endoktriner arka planı, Şii mezhebine bağlı olarak tanzim edildiğinden ve bir üst kimlik olarak kabul edildiğinden (Onat:2013, 226) en önemli ayrışma Şii-Sünni mezhep farklııklarına dayalı olarak belirginleşmektedir.
İran devlet sistemi, etnik ve dini konuların siyasal alana taşınmasına oldukça mesafeli yaklaşmakta, bu türden eğilimleri "fitne" olarak değerlendirmektedir. Örneğin, Dini Lider Hamaney'in Belucistan Sünnilerine yönelik mesafesi bilinmektedir. Diğer taraftan, etnik dini meseleler, bir dereceye kadar İran siyasetinin tartışılan konuları arasında yer almaktadır. Reformcu siyasetçilerin başında gelen Rafsancani, Hatemi ve Ruhani soruna ilişkin çözüm arayışında oldukları izlenimi yaratmayı başarmışlardır.

Azınlık sorunları özellikle seçim dönemlerinde reformcu adayların vaatleri arasında yer almaktadır. 2005 yılında reformist aday Mustafa Moein, kabineye Sünni üyeleri atamak istediğini belirtmiştir. (Selcen, Akgül:2017) Ruhani ise, etnik ve mezhepsel sorunların temelinde ekonomik geri kalmışlığın olduğunu ifade etmekle ve iktisadi kalkınma sözü vermekle yetinmektedir. Bunun yanında Ruhani her türlü etnik ayrımcılığa mesafeli olduğunu ifade etmiştir. Söz konusu vaatlere karşın İran'da, beklentilerin karşılanmasında önemli sıkıntılar bulunmaktadır. Örneğin, Aralık 2016 yılında yasal bağlayıcılığı olmayan "Temel Haklar Bildirgesini" kamuoyu ile paylaşan Ruhani'ye, Yargı Gücü Başkanı Sadık Laricani "Yargının akıl almaya ihtiyacı yok" (Deutsche Welle Türkçe.:2017) diyerek tepkisini ortaya koymuştur.

Buna rağmen, Reformcular ve Muhafazakârlar arasında, ülke içindeki etnik ve dini meseleler çerçevesindeki uygulamada çok fazla farklılık olmamakla birlikte, dini lider ve reformcu cumhurbaşkanları arasında "ülkedeki Batı etkisi" konusu bağlamında sert tartışmaların yaşandığı gözlemlenmektedir. ${ }^{5}$

\footnotetext{
${ }^{5}$ İran'da Ruhani döneminde de kılık kıyafet, saç kesimi ve dövme yaptırmak, Devrimin ilkelerine aykırı olduğu gerekçesiyle, cezalandırılmaya devam etmektedir. hatta 2015 y 1 lında berberlere "uy gun" saç şekillerini gösteren bir liste dağıtılmış ve bu listeye uy gun saç kesimi y apmaları talep edilmiştir. Elahe Izadi, "Iran Bans 'Devil-Worshipping' Spiky Haircuts and Male ey ebrow Plucking", The Washington Post, 5 May is 2015, https://www.washingtonpost.com/news/worldviews/wp/2 015/05/05/iran-bans-devil-worshiping-spiky-haircuts-
} 
Humeyni döneminde Devrimin temel hedefleri arasında sayılan ülkenin Batı kültüründen "arındırıması" ve dine dayalı yaşam (Taşkın:2014, 234) en az ekonomik olarak Batı merkezli şirketlerin gücünün ve nüfuzunun ortadan kaldırıması kadar önemli görülmekteydi. Devrim sonrası kültürel yapının İslamileștirilmesi amacıyla, Kültür Devrimi Yüksek Konseyi gibi çeşitli kurumsal yapılar ortaya çıkmıştır. Bu anlayış çerçevesinde oluşturulan kurumlar, Batı ile her türden temasın kuşkulu bir eğilim olarak değerlendirilmesine de neden olmuştur. Ruhani döneminde de eğitim ve kültürel alanda yapılması düşünülen veya tartışılmaya açılan konular Hamaney tarafından, Dine ve İran geleneklerine aykırı olduğu gerekçesiyle eleştiri konusu yapılmıştır.

Hamaney, ülkenin temel değerlerinin İslam ve Kuran olduğunu belirtirken, Batının "yozlașmış" kültürünü “yıkıcı" olarak nitelendirmektedir. Örneğin, 19 Mayıs seçimleri öncesi Hamaney, Birleşmiş Milletlerin eğitim reformu çerçevesinde UNESCO tarafından tavsiye edilen "Eğitim 2030" planının İran'da uygulanmasına izin verilmeyeceğini belirtmiş ve Ruhani'yi ülkeyi Batı kültürünün etkisine açmakla suçlamıştır. ${ }^{6}$ Ancak yine de belirtmek gerekir ki, Ruhani hiçbir zaman Muhammed Hatemi (Hatemi dönemi reform mücadeleleri için (bkz. Oğuz, Çakır:2008.) kadar kültürel açıdan Batı ile ilişkilere yakın görünmemeye özen göstermiştir. Dikkatini daha ziyade nükleer anlaşma ve ekonomik liberalleşme konularına yöneltmekle birlikte, Hamaney ve güçlü devlet oligarşisi karşısından cumhurbaşkanından ziyade bir muhalefet partisi lideri konumunda eleștirel bir duruş benimsemiş ve bu duruş toplum tarafında da kabul görüşmüştür.

and-male-ey ebrow-plucking/?utm_term=.dea2821c6c43, 05.06.2017.

${ }^{6}$ Ayrıntı için bkz. "İran'da Dini Lider Hamaney'den Ruhani'ye Sert Eleştiriler", Kırım Haber Ajansı, 7 Mayıs 2017, http://qha.com.ua/tr/siy aset/iran-da-dini-liderhamaney-den-ruhani-ye-sert-elestiriler/155580/, 17.06.2017.
Buna ilaveten Ruhani, İran'da ve dünya kamuoyunda çok tartışılan Yeşil Hareketin lideri konumundaki Reformcu aday Mir Hüseyin Musevi'nin ev hapsine son verileceğine dair vaatlerde bulunmuş olmasına rağmen, bu yönde adım atmamıştır. Daha önce, Musevi Hamaney'e açıkça rest çekerek rejimin cumhuriyetçi özelliklerini ortadan kaldırmakla suçlamış ve yaşanan protestoların arkasından ev hapsine alınmıştı. Ruhani, Musevi ve diğer muhalifler Mehdi Karubi, Musevi'nin eşi Zehra Rahnavard'ın serbest kalmasını, Hamaney'in olası tepkisini göze alamadığından sağlayamamıştır. Bu konuda Hamaney ile fiili uzlaşmayı tercih etmiştir. Buna karşlık, Ruhani'nin eleştirel ve uzlaşmacı yönlerini "dengeli” bir şekilde kullanma eğilimi, Hamaney ve muhafazakârların siyasal pozisyonlarının "radikal" olarak görünmesine de neden olmuştur.

Ruhani, Batı ile iyi ilişkiler, ekonomik kalkınma, basın özgürlüğü, düşünce hürriyeti, eşitlik ve siyasi tutukluların serbest kalması gibi konularda söylem olarak güçlü bir pozisyon belirlemiş olmakla birlikte, fiili olarak hareket alanı sınırlı bir cumhurbaşkanı olarak ilk dönemini tamamlamıştır.

\section{Sonuç}

İran siyasal sistemi hiyerarşik bir yapıdadır. Ancak, bu durum beklendiğ́i üzere tam bir uyum yaratmamıștır. Dini lider ve cumhurbaşkanı arasından güç mücadelesi İran siyasetinde her dönem açıkça gözlemlenmektedir. Mücadelenin dozu, reformcu bir cumhurbaşkanı seçildiğinde artmakla birlikte, muhafazakâr bir cumhurbaşkanı ile lider arasında da görüş ayrılıklarının yaşandığı gözlemlenmektedir. Reformcu cumhurbaşkanı ile yaşanan gerilimin nedenleri, genellikle idari, siyasal, ekonomik ve dış politika konularını içerirken, muhafazakâr bir cumhurbaşkanı ile yaşanan gerilimin çoğunlukla yetki paylaşımı ve atamalar gibi idari konular üzerinden kendini belli etliği söylenebilir. 
Bu nedenle muhafazakâr bir cumhurbaşkanının seçilmesi, sistem içi tam bir siyasal uyumun olduğu anlamına gelmemektedir. Örneğin Ahmedinejad döneminde, İran'da Hac organizasyonu yapan bir kuruma Cumhurbaşkanı tarafından yapılan atama Hamaney tarafından geri alınmıştır. Bu durum Hamaney ve Ahmedinejad arasında anlaşmazlık konusu olarak öne çıkmakla birlikte, siyasi ve ekonomik açıdan Ahmedinejad'ın ülke içinde ve dışından yoğun bir şekilde eleştirilmesi ve güç kaybetmesi ile bağlantılı bir şekilde değerlendirilmektedir. Muhafazakâr pozisyonuna rağmen Hamaney'in statükoyu koruma ve riskten kaçınma eğilimi, Ahmedinejad ile çatışma yaşamasına neden olmuştur. Illaveten Ahmedinejad'ın dış politikası, İran'da milli kimliğin dini kimliğe göre konumunun ve öneminin tartışılmasına neden olmuştur. Benzer bir durum Ruhani dönemi için de geçerlidir.

Ruhani'nin birinci dönemi, Ortadoğu'da kaosun ve istikrarsızlığın egemen olduğu ve ABD'de Obama yönetiminde Demokratların bölge siyasetine yeniden yön vermeye çalıştığı bir zamana tekabül etmektedir. Küresel ve bölgesel gelişmelerin etkisi ile ilk döneminde eli hayli güçlü olan Ruhani, bu gücünü iç politikada etkinliğini arttırmak suretiyle pekiştirmeye çalışmıştır.

Kuşkusuz Hatemi ve Rafsancani'nin desteği ile birlikte, Ahmedinejad döneminin yarattığı öfke nedeniyle orta sınıf ve kentli kesimlerinin gücünü arkasında bulması da Ruhani için önemli bir avantaj sağlamıştır. İçerde ve dışarıda gücünü arttıran Ruhani, DM'na ve lider Hamaney'e karşı belli ölçüde direnç gösterebilmiştir. Bu bağlamda, Ruhani, lider Hamaney'in açıklamalarını cevapsız bırakmamaya, açıktan eleştiri niteliğinde pek olmasa da sitemkâr tutumunu ifade etmeye özen göstermiştir.
Bununla birlikte, liderin gücü ve yetkileri kolaylıkla tartışma konusu yapılamamakta, dolaylı olarak liderin gücünü pekiştiren kurumlar, ekonomik yapılar ve dış düşman algısını belirleyen söylemlerin tartışılmaya açıldığı görülmektedir.

İran'da dini liderin konumu, yetkileri ve kontrol ettiği muazzam ekonomik ve askeri mekanizma, reformcu siyasilerin fiili olarak önündeki en önemli engellerden birisi olmuştur. Hamaney'in 1981 yılında Cumhurbaşkanı ve 1989 yılında da lider olduğu göz önünde bulundurulduğunda, cumhurbaşkanının konumu hayli zayıf görünmektedir. Ancak bu durum, toplumsal ve uluslararası değișkenlere bağlı olarak farklılıklar göstermektedir.

Ruhani, birinci döneminde Hatemi ve Rafsancani'nin katkısı ve \%51 oranında halk desteği ile seçimi kazanarak cumhurbaşkanı olmuştur. 19 Mayıs 2017 Tarihinde Rafsancani gibi önemli bir aktörün desteği olmadan $\% 58$ oranında oy almasına rağmen Ruhani'nin İran siyasetinde kısa ve orta vadede etkisinin azalması beklenebilir. Buna karşılık olarak Hamaney ve askeri bürokrasinin gücünün artacağı bir dönem başlamış bulunmaktadır. 


\section{Kaynakça}

Abrahamian, Ervand (2008). Modern İran Tarihi. çev: Dilek Şendil. İstanbul: İş Bankası Yayınları,

Alaca, Mehmet, "Iran Dış Politikasını Velayeti Fakih Kurumu Üzerinden Okumak", Süreç Analiz, 1 Mart 2013, http://www.surecanaliz.org/tr/article/iran-dis-politikasini-velayet-ifakih-kurumu-uzerinden-okumak, 12.07.2017.

Avaei, Kourosh, “iran Devrim Muhafızları'nın Ekonomik Rolü Azalacak Mı?”, http://www.almonitor.com/pulse/tr/originals/2013/og/rouh ani-asks-revolutionary-guard-scale-back.html, 15.07.2017.

Cladstone, Rick, “Iran's Top Leader Appears to Rebuke President as Election Nears", The New York Times, 9 Mart 2017 https://www.nytimes.com/2017/03/09/world/ middleeast/iran-economic-growth-khameneirouhani.html, 12.06.2017.

Çagaptay, Soner, James F. Jeffrey, Mehdi Khalaji, "Iran Won't Give Up on Its Revolution", The New York Times. 26 Nisan 2015.

http://www.nytimes.com/2015/04/27/opinion/ iran-wont-give-up-on-its-revolution.html. 06.05.2016.

Çağlayan, Selin (2012). İran Mehdiyi Beklerken. İstanbul: Cinius Yayınları.

Çitlioğlu, Ercan (2015). İran'ı Anlamak. Ankara: Başkent Üniversitesi Yayınları.

Dabashi, Hamid (2011) The Green Movement in Iran. New Brunswick: Transaction Publishers.

Green, D. Jerrold, Frederic Wehrey, Charles Wolf, Jr. "Understanding Iran", National Security Research Division, 2009, http://www.rand.org/content/dam/rand/pub s/monographs/2008/RAND_MG771.pdf, 04.07.2017.
Gregory, Mark, "Expanding Business Empire of Iran's Revolutionary Guards", BBC News. 26 Haziran 2010, http://www.bbc.comLnews/world-middle-east-10743580, 05.07.2017.

Hakimian, Hassan, “Iran's Economy After the Elections", 7 Mart 2016, https://www.projectsyndicate.org/commentary/iran-economicchallenges-after-elections-by-hassanhakimian-2016-03?barrier=accessreg, 12.07.2017.

http://www.vatanemrooz.ir/

Iran (Islamic Republic of)'s Constitution of 1979 with Amendments through 1989, https://www.constituteproject.org/constituti on/Iran_1989.pdf?lang=en, 19.07.2017.

Izadi, Elahe, “Iran Bans 'Devil-Worshipping' Spiky Haircuts and Male eyebrow Plucking”, The Washington Post, 5 Mayıs 2015, https://www.washingtonpost.com/news/wor Idviews/wp/2015/05/05/iran-bans-devilworshiping-spiky-haircuts-and-maleeyebrowplucking/?utm term $=$. dea2 $821 c 6 c 43$ , 05.06.2017.

İran: Ruhani'nin Vaatlerinde Geriye ne Kaldı?, Deutsche Welle Türkçe, http://www.dw.comtrr/iran-ruhaninin-vaatlerinden-geriye-nekald\%C4\%B1/g-38884878, 22.06.2017.

İran'da Askerin Rolü, Anadolu Ajansı, http://aa.com.tr/tr/analiz-haber/irandaaskerin-ekonomide-rolu-tartismasi/560957, 05.06.2017.

İran'ın Savunma Bütçesi Yüzde 39 Arttı, NTV, 9 Aralık 2016, http://www.ntv.com.tr/dunya/iranin-savunma-butcesi-yuzde-39artti, gM-LCFoYRUq6uN5ZnFhDmQ, 17.07.2017.

İran'da Dini Lider Hamaney'den Ruhani'ye Sert Eleştiriler, Kırım Haber Ajansı, 7 Mayıs 2017, http://qha.com.ua/tr/siyaset/iran-dadini-lider-hamaney-den-ruhani-ye-sertelestiriler/155580/, 17.06.2017.

Kılınç, Ahmet (2008). “İan Anayasa Hukukunun Genel Esasları”, Gazi Üniversitesi Hukuk Fakültesi Dergisi C. XII, Sa. 1-2, ss. 907948. 
Kissinger, Henry George P. Shultz, "The Iran Deal and Its Consequences", The Wall Street Journal, 7 Mart 2015, https://www.wsj.comlarticles/the-iran-deal-and-its-consequences1428447582, 23.06.2017.

Kohlmann, Thomas, "Iran Ekonomisinin İpleri Onların Elinde", Deutsche Welle Türkçe, 18 şubat 2016, http://www.dw.com/tr/iranekonomisinin-ipleri-onlar\%C4\%B1n-ellerinde/a19056198, 13.06.2017.

Mansfield, Peter (2011). Ortadoğu Tarihi. Ümit Hüsrev Yolsal (çev.). İstanbul: Say Yayınları

Oğuz, Sami, Rușen Çakır (2000). Hatemi'nin İran'ı. İstanbul: İletişim Yayınları.

Onat, Hasan (2013). "Iiran İslam Devrimi ve Şiilik”. Mezhep Araştırmaları, VI/2, ss. 223-256.

Selcen, Nazife, Pınar Akgül, “iran’da Etnik ve Dini Çatışmalar”, IRAM, 06 Mayıs 2017, http://iramcenter.org/iranda-etnik-ve-dinicatismalar, 16.06.2017.

Sinkaya, Bayram (2010). “Iran'da AskerSiyaset ilişkileri ve Devrim Muhafızları'nın Yükselişi”, Ortadoğu Etütleri, Cilt 1, Sayı 2, ss. 115-142.

Sinkaya, Bayram "Ruhani Döneminde Devrim Muhafızları ve Siyaset", ORSAM, 15 Ağustos 2016, http://www.orsam.org.trindex.php/Content/Analiz/4826?s=orsam\%7C turkish, 12.06.2017.
Secor, Laura, "The Patient Resilience of Iran's Reformers", The New York Times, 02 Mayis .2017 https://www.nytimes.com/2017/05/22/opinio n/iran-election-reformers.html, 17.06.2017.

Taflıoğlu, Serkan (2013). "İran İslam Cumhuriyeti'nde Egemenlik ve Meşruiyet Kaynağı "Velayet-i Fakih"”, Ankara Üniversitesi SBF Dergisi, Cilt 68, No. 3, s. 95112,http://dergiler.ankara.edu.tr/dergiler/42/1 812/19141.pdf, 23.06.2017.

Tașkın, Yüksel (2014). "iran: Yol Ayrımında Bir Devlet ve Toplum", Y.Doğan Çetinkaya (ed). Ortadoğu: Direniş, Devrim, Emperyaliz. içinde. İstanbul: iletişim Yayınları, ss. 219-267.

Yeğin, Abdullah (2016). "Iran'ın Sert Gücü", SETA, Sayı 150, https://stratejisite.files.wordpress.com/2016/02/rann-sert-gc.pdf, 12.06.2017. 